\title{
THE EFFECT OF TEACHING CULTURAL CONTENT ON INTERMEDIATE EFL LEARNERS' READING COMPREHENSION ABILITY
}

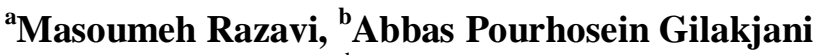 \\ (aa.razavi.j@gmail.com, babbas.pourhossein@yahoo.com) \\ Department of English Language Translation, \\ Lahijan Branch, Islamic Azad University, Lahijan, Iran
}

\begin{abstract}
This study investigated the effect of teaching cultural content on Iranian intermediate English as a foreign language (EFL) learners' reading comprehension. To this end, 60 intermediate EFL learners from Shokouh Institute in Motelqu, Mazandaran, Iran were selected randomly and assigned to two groups, namely the control group and experimental group; 30 participants in each group were chosen based on their performance using the Oxford Placement Test (OPT). This study used a quasi-experimental, pretest-posttest control group research design. After the OPT, the reading comprehension pre-test was given to the participants to check their initial reading comprehension. During a sixweek treatment period, both control and experimental groups received the same routine lesson plan of the institute but only the experimental group enjoyed the culture instruction in order to test its effect on learners' reading comprehension improvement. At the final stage, the post-test was given to check their reading comprehension after the six-week treatment period. The data were analyzed using an Independent Samples T-test and a series of paired Samples T-tests. The results of this study showed that receiving cultural content instruction improved learners' reading comprehension. In general, the results of experimental group supported the effect of teaching cultural content on Iranian learners' reading comprehension.
\end{abstract}

Keywords: cultural content, EFL learners, reading comprehension

DOI: http://dx.doi.org/10.15639/teflinjournal.v31i2/302-321

A lot of research suggests integrating culture learning into second or foreign language learning curriculum (Brown, 2007; Choudhury, 2014; Christiansen \& 
Silva, 2016; Karimi, \& Nafissi, 2017; Schulz, 2007; Tomalin, 2008; Wang, 2008). One of the main reasons behind foreign language teaching is to increase EFL learners' intercultural communicative competence, which is the ability to interact effectively with the native speakers of another language and culture (Gulbinskienè \& Lasauskienè, 2014). Such communicative ability is incomplete without cultural awareness, which is explained as the knowledge gained not only about the other culture, but also about one's own culture (Serna Dimas, 2016). This awareness includes the ability to find out one's own cultural viewpoints (the ability to indicate one's own cultural identity, beliefs, and values) and make a comparison between one's own culture and that of the interlocutor's.

Learning about the culture of the target language speakers and about one's own culture needs tools that help learners in negotiating meaning and comprehending the communicative and cultural texts in which linguistic codes are utilized (Kilickaya, 2004; Stuart \& Nocon, 1996). Cultural content provides exposure to living language that a foreign language learner lacks. Therefore, culture is not something involving facts to be learnt, but a useful tool to make learners feel the need to speak and use the target language effectively (Kilickaya, 2004; Shanahan, 1997). McKay (2000) believes that there should be a variety of culture in the materials in language classrooms. She further specifies three kinds of cultural materials: target culture materials, learners' own culture materials and international target culture materials. The best one is international target language materials, which include a variety of knowledge from various cultures. This will enhance the learners' interest rather than imposing just one culture all the time. It prevents learners from having the fear of assimilation into a particular culture, and assist them in respecting other people's cultures. Tomalin (2008) also argued that cultural teaching in English language teaching involves cultural knowledge (knowledge of culture's institution), cultural values (the psyche of the country, what people think is important), cultural behavior (knowledge of daily routines and behavior), and cultural skills (the development of intercultural sensitivity and awareness, using English language as the medium of interaction). Including culture into language teaching also means integrating different cultural concepts from learners' social, semantic, and pragmatic viewpoints (Liu, 2015; Tsou, 2005). In this study, we will specifically discuss the integration of cultural content into the teaching of reading and its effects on comprehension. 
With regard to reading in a foreign language, one crucial determinant of reading comprehension is the amount of background knowledge readers have. Although readers can turn printed symbols into sounds and word accurately, it cannot guarantee their comprehension. Inadequate background knowledge especially cultural one can have an effect on reading comprehension. The integration of L1 culture into educational curricula has a key role in successful reading comprehension (Karimi, \& Nafissi, 2017; Ketchum, 2006). One of the reasons that explains this case is Schuman's "Schema Theory." According to Al-Issa (2006), Brown (2001), and Karimi and Nafissi (2017), schemata are the background knowledge, feelings, experiences, principles, ideas, judgments that a reader brings to a text or printed page. There are three main kinds of schemata: formal or textual, content, and cultural, which have a near relationship with reading comprehension. Cultural schema refers to the cultural background knowledge which is necessary for comprehending a text and the purposes of its writer. It includes the type of knowledge that is attained through being a member of a specific group and involves the total set of beliefs, values, attitudes, customs, and behaviors held by that particular group (Ketchum, 2006). This concept assists readers in rebuilding the author's message(s) by predicting the way in which the text develops.

EFL learners' reading comprehension skill is decreased when they are exposed to a reading text with the cultural orientation different from their own (Ketchum, 2006). When learners encounter a reading text based on a new content and culture with which they are not familiar, they must perform both micro-level textual analysis (letter identification or pattern recognition) and macro-level textual analysis (activation of prior knowledge and monitoring comprehension) in order to understand the text. Both of these analyses need attention, working memory space, and cognitive processing (Brantmeier, 2004). When learners are exposed to the reading texts based on L1 culture or the content and culture they are familiar with, they will have more attention and memory space for both micro- and macro-level textual analysis. The reason is that the readers would activate and bring the relevant content and cultural background knowledge and schema to the reading process. As a result, reading needs less cognitive processing since macro-level textual analysis is conducted automatically which leads to higher levels of reading comprehension and achievement (Carrell, 1988).

Cultural background knowledge plays an important role in understanding the texts in curricula. It influences not only the comprehension scores and the 
recall of text propositions, but also the reading effectiveness of learners learning the language. Harmer (2001) states that a reader should have some clues to understand the writer's meaning and concepts. Thus, when texts have cultural concepts that are unfamiliar for the foreigners, they must have some clues as pre-reading activities. It is necessary for teachers to discuss the new cultural concepts to pave the way of learners' reading comprehension. Learners should be familiar with the language culture that really helps them to learn it effectively. Therefore, teachers should pay attention to the capability of their learners through using techniques that increase cultural understanding.

Some studies have been conducted about the effect of teaching cultural content on learners' reading comprehension skill. Emsley's (2011) study, for example, revealed that English as a Second Language (ESL) learners' cultural background has an impact on understanding the texts. The results also indicated that cultural background facilitates learners' reading comprehension. Moreover, Ibrahim (2013) examined the impact of cultural background knowledge on learners' performance in reading comprehension. Sixty students participated in his study and were divided into four groups, two experimental and two controlled. The data were analyzed via means, standard deviations, and Pearson Product Moment Correlation. The findings indicated that there are significant differences in performance in reading comprehension between students who have cultural background knowledge and those who do not have any knowledge.

Furthermore, Ghaderpour (2013) carried out a study to discover the significance of cultural background knowledge toward reading comprehension. A quantitative method was used and 30 Iranian students participated in this study. In order of identify the role of cultural background knowledge, the original and nativised texts were given to the participants. The obtained results showed that cultural background knowledge enhances the comprehension of reading text.

By the same token, Liu (2015) investigated the effect of cultural background knowledge on Taiwanese learners' reading comprehension. Fifty Taiwanese EFL students took part in this research. The researcher used a questionnaire to see how cultural background knowledge affects reading comprehension. The findings obtained from this study showed that students who had better cultural knowledge were able to understand English contents effectively. The findings also revealed that cultural background knowledge had 
a significant impact on promoting intermediate EFL learners' reading comprehension.

Some studies have also been conducted in the last ten years on the effect of teaching cultural content on EFL learners' reading comprehension in Iran. Rashidi and Heidari Soureshjani (2011) investigated whether teaching the cultural texts to Persian EFL learners has any impact on their performance on reading comprehension tests. One hundred and two Persian EFL learners (belonging to two classes) were sampled, using convenient sampling. The experimental group was given the treatment (teaching cultural texts). The results demonstrated that teaching culture elements of target language can have a great impact on the performance of language learners on reading comprehension tests.

In addition, Ghorbandordinejad and Bayat (2014) investigated the effect of cross-cultural foundation information on Iranian EFL learners' reading comprehension. The results of their study revealed that familiarity with specific culturally-oriented language reading content improved Iranian EFL learners' reading comprehension. Finally, Narimani (2017) aimed to examine the effects of integrating cross-cultural content in reading instruction on Iranian EFL learners' reading comprehension at low and advanced levels of language proficiency. The study was done in two phases: Treatment and evaluation. During the treatment, the researcher familiarized the low and advanced students to the target cultural values and norms. After the treatment, all participants took a post-test. The results of Paired sample t-test indicated that cross-cultural background knowledge had significant effects on the reading comprehension of learners with higher levels of proficiency, but low level learners did not show significant improvement in their reading comprehension.

According to the studies, it was indicated that culturally bound prior knowledge influences learners' reading comprehension. Culturally-related reading materials assist learners' overall reading skill because these materials aid learners to form conceptual scaffolds (McCullough, 2008). Teachers should know how to embed cultural materials into their classes in order to expand learners' global perspectives. They should also know how to activate learners' prior linguistic and cultural backgrounds to improve their reading comprehension (Liu, 2015; Tseng, 2002). Incorporating cultural differences and cultural background knowledge into the language classes is useful for both teaching and learning. Teachers should increase learners' cultural awareness to improve their levels of reading comprehension proficiency (Guest, 2002). 
As it has been discussed, a number of studies have been conducted with regards to the impact of cultural familiarity on reading comprehension. Yet, to the best of our knowledge, few studies have been done in Iranian academic setting concerning the effect of teaching cultural content (here cultural background knowledge) on the development of EFL learners' reading comprehension ability. Hoping to fill this gap, the present study set out to investigate the impact of teaching cultural content on the reading comprehension ability of Iranian EFL learners. Therefore, the goal of this paper is to see whether teaching reading by incorporating the development of cultural background knowledge as one of the aspects of cultural content has any significant effect on improving learners' reading comprehension. Based on that, the following research question and hypothesis were proposed for the study:

Question: Does teaching cultural content have any significant effect on Iranian intermediate EFL learners' reading comprehension?

Hypothesis: Teaching cultural content does not have any significant effect on Iranian intermediate EFL learners' reading comprehension.

\section{METHOD}

This study made use of a quasi-experimental, pretest-posttest control group research design. It adopted quantitative methodology to look into the effect of teaching culture on EFL learners' reading comprehension. The following is an overview of the research process. Firstly, a test named Oxford Placement Test (OPT) was administered among the participants to select a homogenous sample, i.e. intermediate language learners. After the OPT, a reading comprehension pre-test was given to the participants to check their initial reading comprehension ability. During a six-week treatment period, both control and experimental groups received the same routine lesson plan of the institute but only the experimental group enjoyed the culture instruction in order to test its effect on learners' reading comprehension improvement. At the final stage, a post-test was given to the participants to check their reading comprehension ability after the six-week treatment period. These test instruments and the treatment process for the experimental group will be explained in more detail in later parts of this method section. 
This study was conducted with 60 Iranian intermediate EFL learners who were studying in Shokouh Language Institute in Motelqu, Mazandaran to examine the effect of culture instruction on their reading comprehension. The researchers attempted to have the same number of female and male participants in both experimental and control groups. All participants were aged 13 to 15 years old. Based on the OPT test direction, the 60 intermediate students who scored +31 in grammar and vocabulary and +8 in reading section were chosen as the main sample out of 146 students. Then, they were assigned in two groups (one control and one experimental) with 30 students in each group.

Two different instruments for collecting data were used in the present study: the OPT and Reading comprehension pre-test and post-test. OPT was employed to homogenize participants in terms of their level of proficiency, i.e. intermediate learners for the purpose of data collection. The OPT provides teachers with a reliable and efficient means of placing students at the start of a course. It involves a carefully selected range of items with facility values and discrimination indices designed to provide meaningful discrimination at each of the levels identified by the Common European Framework. The test is also provided with a written key to help marking the tests (Allen, 1985). The test contains 50 multiple choice questions which assess students' knowledge of key grammar and vocabulary from elementary to intermediate levels, and a reading text with ten graded comprehension questions. The test was used to determine the proficiency level of participants to choose 60 participants from among 146 learners. The 60 chosen participants were at intermediate level. Based on the OPT test, 60 intermediate students who scored +31 in grammar and vocabulary and +8 in reading section were chosen as the main sample for the present study.

After the administration of the OPT, a reading comprehension pre-test, which is based on the course syllable content, was administered before the treatment to distinguish the learners' initial knowledge of reading comprehension. The other reading comprehension test was used as the post-test to check the participants' reading comprehension ability after the treatment. These two tests were made by the researchers. They consisted of two passages in intermediate level that were extracted from "English in common" and "American English file" (intermediate level) course books which are two common course books in Iran. The researchers selected the reading passages from the mentioned books because the EFL learners had already learned them in English Institutes and had cultural familiarity, prior knowledge, and keen interest towards them. The books involved socially or culturally familiar texts 
that arouse much interest in EFL learners towards reading them. As to the reliability measure of the pre-test, a pilot study was conducted with the participation of 30 intermediate students (from another private institute with similar characteristics of the participants of the present study). Reliability coefficient was found to be 0.76 for the pre-test and 0.78 for the post-test (using KR-21 formula), which seemed to be a reasonable value in terms of consistency of scores as highlighted in Farhady et al. (1994). In addition, two Associate Professors of Teaching English as a Foreign Language (TEFL) confirmed the validity of the pre-test and post-test. The reliability of the pretest and post-test is shown in Table 1 and Table 2.

Table 1. Reliability of the Reading Comprehension Pre-test

\begin{tabular}{cccc}
\hline $\mathbf{N}$ & Mean & SD & Reliability \\
\hline 30 & 85.00 & 5.78 & 0.76 \\
\hline
\end{tabular}

Table 2. Reliability of the Reading Comprehension Post-test

\begin{tabular}{cccc}
\hline $\mathbf{N}$ & Mean & SD & Reliability \\
\hline 30 & 87.12 & 7.01 & 0.78 \\
\hline
\end{tabular}

The experimental group in this study attended five treatment (teaching) sessions of culture instruction provided by the teacher. Treatment refers to the number of sessions the teacher devoted to teaching cultural issues before the post-test to see whether teaching cultural content has any effect on Iranian intermediate EFL learners' reading comprehension. The students learnt the cultural and social concepts of the reading passages, the target cultural values and norms, and the differences between the source and the target language culture. The purpose of incorporating the cultural content in the teaching of reading was to develop the students' cultural background knowledge, and increase their awareness of and curiosity towards the cultural concepts, attitudes, and beliefs. The control group attended five sessions of teaching reading comprehension without receiving culture instruction. It should be noted that the researchers themselves took the role of the teacher to hold the treatment sessions of both groups. After five sessions of treatment in both groups, the participants took the reading post-test. The test was used to measure the groups' achievement of reading comprehension, and to find out whether there is a possible significant effect of teaching culture on Iranian EFL learners' reading comprehension. 
The data analysis of quantitative measures included both descriptive and inferential statistics to measure the impact of culture instruction on the learners' improvement in reading comprehension. To do so, the learners' reading comprehension pre- and post-tests were quantitatively analyzed using the Statistical Package for the Social Sciences (SPSS) software (version 22). The descriptive statistics showed the development of the mean scores on the two occasions of the pre- and post-tests. Additionally, inferential statistics included independent sample t-test to measure the effectiveness of the treatment sessions on the learners' performance in reading tests and compare the results of the two groups to see which of the two groups performed better in terms of improving their reading after the instruction.

\section{FINDINGS AND DISCUSSION}

\section{Findings}

This section highlights the main findings of the current study with respect to the research question. The study aimed at examining the effect of teaching cultural content on the learners' reading comprehension. In order to answer the research question of the study, statistical analyses were carried out. Initially, the normal distribution of data has been checked as in Table 3 .

Table 3. Normal Distribution of the Scores of Reading Comprehension Test

\begin{tabular}{llccc}
\hline \multirow{2}{*}{ Groups } & \multicolumn{3}{c}{ Shapiro-Wilk } \\
\cline { 2 - 5 } Pre-test & Statistics & Df & Sig. \\
\cline { 2 - 5 } & Culture & .940 & 29 & .244 \\
\cline { 2 - 5 } Post-test & Control & .915 & 29 & .120 \\
\cline { 2 - 5 } & Culture & .910 & 29 & .064 \\
\cline { 2 - 5 } & Control & .916 & 29 & .128 \\
\hline
\end{tabular}

As Table 3 shows, sig-values for the pre- and post-test of the culture group are .244 and .064 , respectively. Similarly, the same sig-values for the control group equal .120 and .128 , respectively. The sig-values are more than 0.05 , which meet the normality assumptions. In Table 4, descriptive statistics of the pre- and post-test results of learners who received culture instruction are provided. 
Razavi \& Gilakjani, The Effect of Teaching Cultural Content on Reading 311

Table 4. Descriptive Statistics for the Reading Comprehension Scores of the Culture Group

\begin{tabular}{ccccc}
\hline & Mean & N & Std. Deviation & $\begin{array}{c}\text { Std. Error } \\
\text { Mean }\end{array}$ \\
\hline Pre-test & 74.6500 & 30 & 3.81514 & .85309 \\
\hline Post-test & 87.6500 & 30 & 5.28429 & 1.18160 \\
\hline
\end{tabular}

Table 4 demonstrates the increase in the learners' mean scores from the pre-test $(\mathrm{M}=74.65, \mathrm{SD}=3.81)$ to the post-test $(\mathrm{M}=87.65, \mathrm{SD}=5.28)$, which denotes that teaching cultural content could possibly result in improving the learners' reading comprehension. The difference between the mean scores of the pre- and post-test is shown in Figure 1.

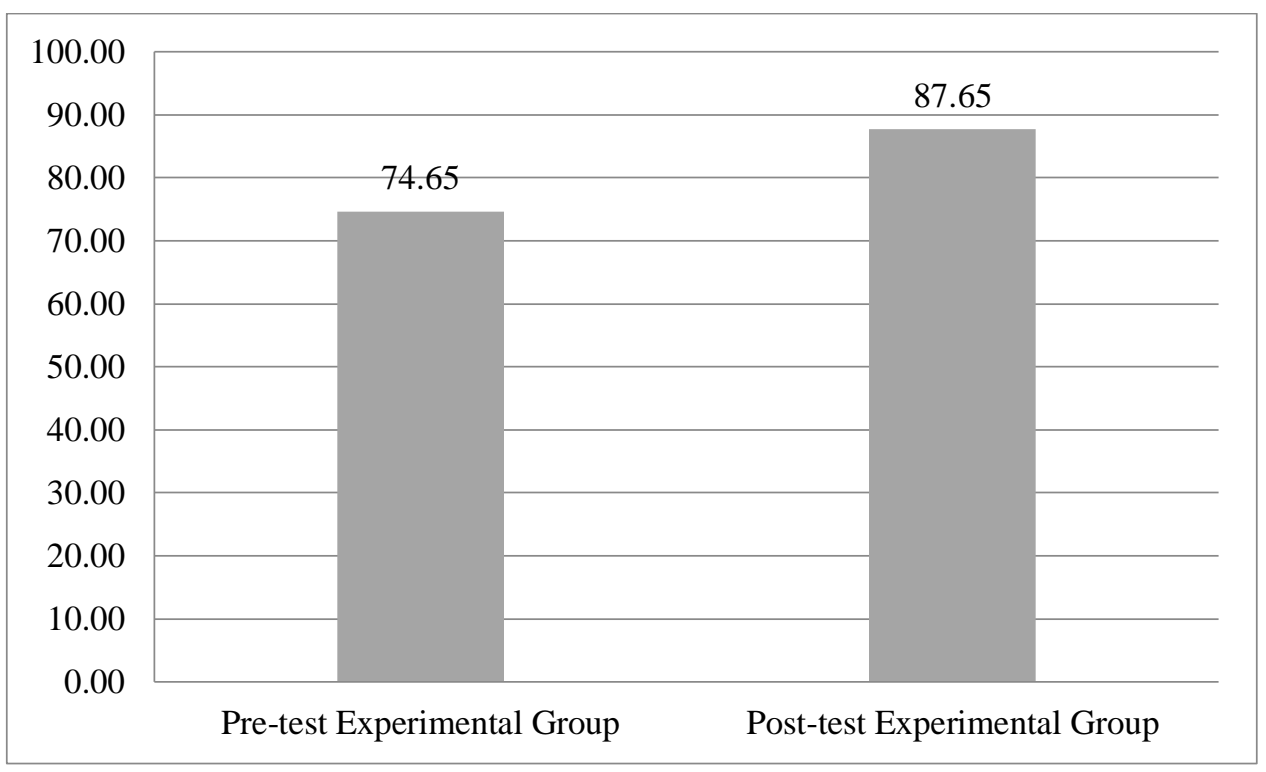

Figure 1. Reading Comprehension Scores of the Experimental Group

In order to show whether there existed a significant difference between the learners' mean scores in the pre- and post-test of reading comprehension, paired samples t-test (Table 5) was run to examine the reading comprehension of learners who received culture instruction. 
Table 5. Paired-Samples T-test for the Reading Comprehension of Culture Group

\begin{tabular}{|c|c|c|c|c|c|c|c|c|}
\hline & \multicolumn{5}{|c|}{ Paired Differences } & \multirow{3}{*}{$\mathbf{t}$} & \multirow{3}{*}{ Df } & \multirow{3}{*}{ T: } \\
\hline & \multirow[t]{2}{*}{ Mean } & \multirow{2}{*}{ 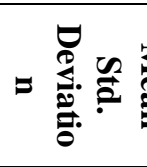 } & \multirow{2}{*}{ 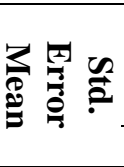 } & \multicolumn{2}{|c|}{$\begin{array}{c}\text { 95\% Confidence } \\
\text { Interval of the } \\
\text { Difference }\end{array}$} & & & \\
\hline & & & & Lower & Upper & & & \\
\hline $\begin{array}{l}\text { Pre-test } \\
\text { Post- } \\
\text { test }\end{array}$ & -13.00000 & $\begin{array}{c}2.8837 \\
1\end{array}$ & $\begin{array}{c}.6448 \\
2\end{array}$ & -5.34962 & $\begin{array}{c}- \\
2.6503 \\
8\end{array}$ & $\begin{array}{c}- \\
6.20 \\
3\end{array}$ & 58 & .000 \\
\hline
\end{tabular}

The results of the paired samples t-tests revealed that the level of significance is less than $.05(\mathrm{p}=.000 \quad \mathrm{Df}=58 \mathrm{t}=-6.20)$, highlighting a significant difference between the experimental group's mean scores of the pre- and post-test. The mean difference is -13.00 . Therefore, receiving cultural content instruction improved the learners' reading comprehension. After comparing the pre- and post-test of the learners who benefited from teaching cultural content, the experimental and control groups are taken into account. Table 6 indicates the two groups' performance in the reading comprehension pre-test.

Table 6. Descriptive Statistics for the Pre-test of the Culture and the Control Groups

\begin{tabular}{lllccc}
\hline & Groups & N & Mean & $\begin{array}{c}\text { Std. } \\
\text { Deviation }\end{array}$ & $\begin{array}{c}\text { Std. Error } \\
\text { Mean }\end{array}$ \\
\hline $\begin{array}{l}\text { Pre- } \\
\text { test }\end{array}$ & Culture & 30 & 74.6500 & 3.81514 & .85309 \\
\cline { 2 - 6 } & Control & 30 & 74.2353 & 2.38562 & .57860 \\
\hline
\end{tabular}

Descriptive statistics of the pre-test of the culture and the control groups denotes that the experimental $(\mathrm{M}=74.65, \mathrm{SD}=3.81)$ and control groups $(\mathrm{M}=$ 74.23, $\mathrm{SD}=2.38$ ) mean scores acted almost similarly before the treatment sessions. Figure 2 shows the comparison of the two groups' performance for the pre-test. 
Razavi \& Gilakjani, The Effect of Teaching Cultural Content on Reading 313

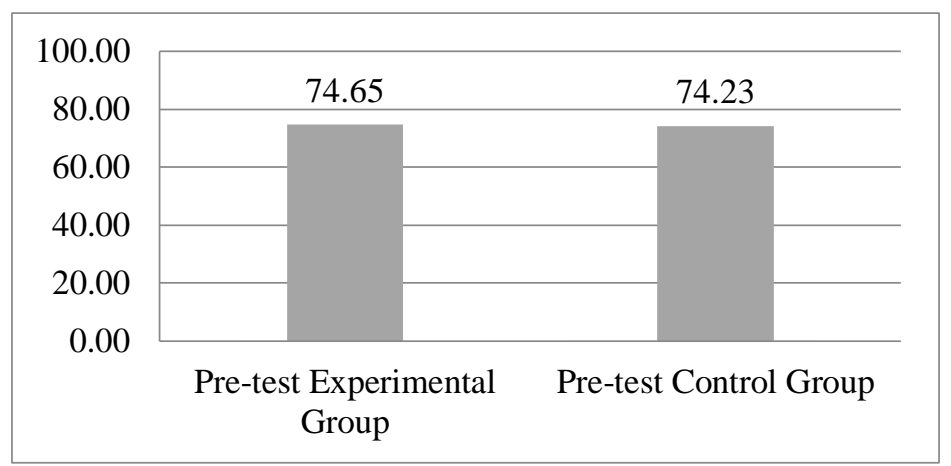

Figure 2. Pre-test Scores of the Experimental and the Control Groups

In order to measure the significance level of the difference between the pre-test scores of the experimental group and the control one, independent samples t-test was run (Table 7).

Table 7. Independent-Samples T-test for the Pre-test Scores of the Culture Group and the Control Group

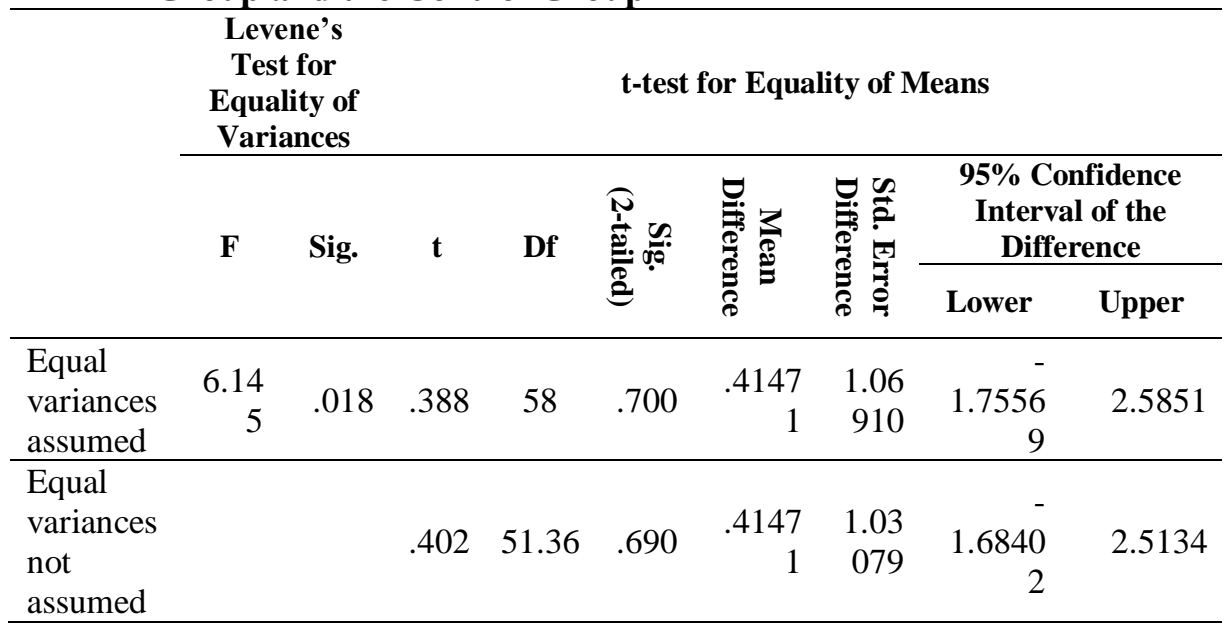

As Table 7 shows, $p$-value from Leven's test is below .05 ( $p=.018)$, which does not meet the equality of the variance for the two groups. The result of independent samples t-test demonstrates that the level of significance is more 
than $.05(\mathrm{p}=.690, \mathrm{df}=51.36, \mathrm{t}=.40)$, revealing no significant difference between the reading comprehension of the two groups. The mean difference is .41 , denoting very little difference. The descriptive statistics for the reading comprehension post-tests of the culture and control groups are shown in Table 8.

Table 8. Descriptive Statistics for the Post-test of the Culture and the Control Groups

\begin{tabular}{llcccc}
\hline Groups & N & Mean & $\begin{array}{c}\text { Std. } \\
\text { Deviation }\end{array}$ & $\begin{array}{c}\text { Std. Error } \\
\text { Mean }\end{array}$ \\
\hline $\begin{array}{l}\text { Post- } \\
\text { test }\end{array}$ & Culture & 29 & 87.6500 & 5.28429 & 1.18160 \\
\cline { 2 - 6 } & Control & 29 & 78.2941 & 2.39178 & .58009 \\
\hline
\end{tabular}

Table 8 reveals much difference between the post-test mean scores of the experimental group $(\mathrm{M}=87.65, \mathrm{SD}=5.28)$ and the control group $(\mathrm{M}=78.29$, $\mathrm{SD}=2.39$ ). The mean difference of the two groups is illustrated in Figure 3.

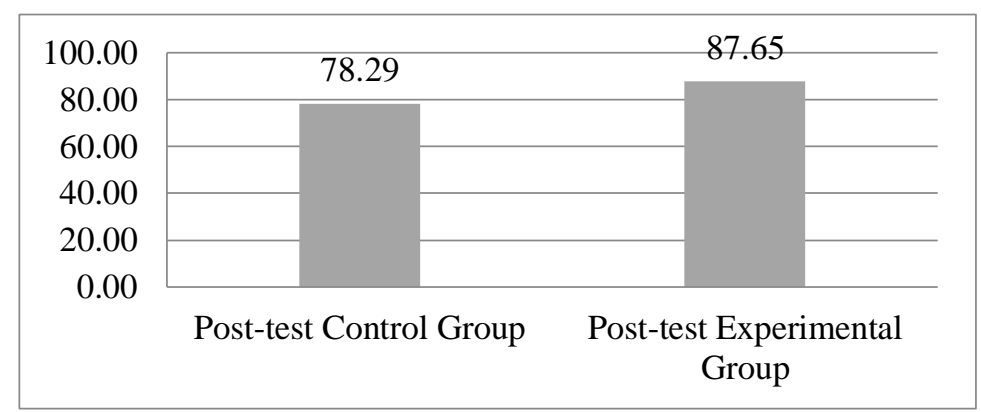

Figure. 3 Post-test Scores of the Experimental and the Control Groups

In order to inferentially compare the experimental and control learners' reading comprehension after the treatment sessions, independent samples t-test was run (Table 9).

According to Table 9, p-value which resulted from Levene's test is less than $.05(\mathrm{p}=.001)$. It reveals that the variance of the scores for the two groups was not equal. The second line of the Table demonstrates that the significance level is less than $.05(\mathrm{p}=.003, \mathrm{Df}=50.37, \mathrm{t}=3.30)$, showing significant difference between the experimental group and the control one. The mean difference is 9.35 , which is rather high. Therefore, it can be concluded that the 
null hypothesis of the study is rejected and the strategy of teaching culture could result in significant improvement in the learners' reading comprehension.

Table 9. Independent-Samples T-test for the Post-test Scores of the Culture and the Control Groups

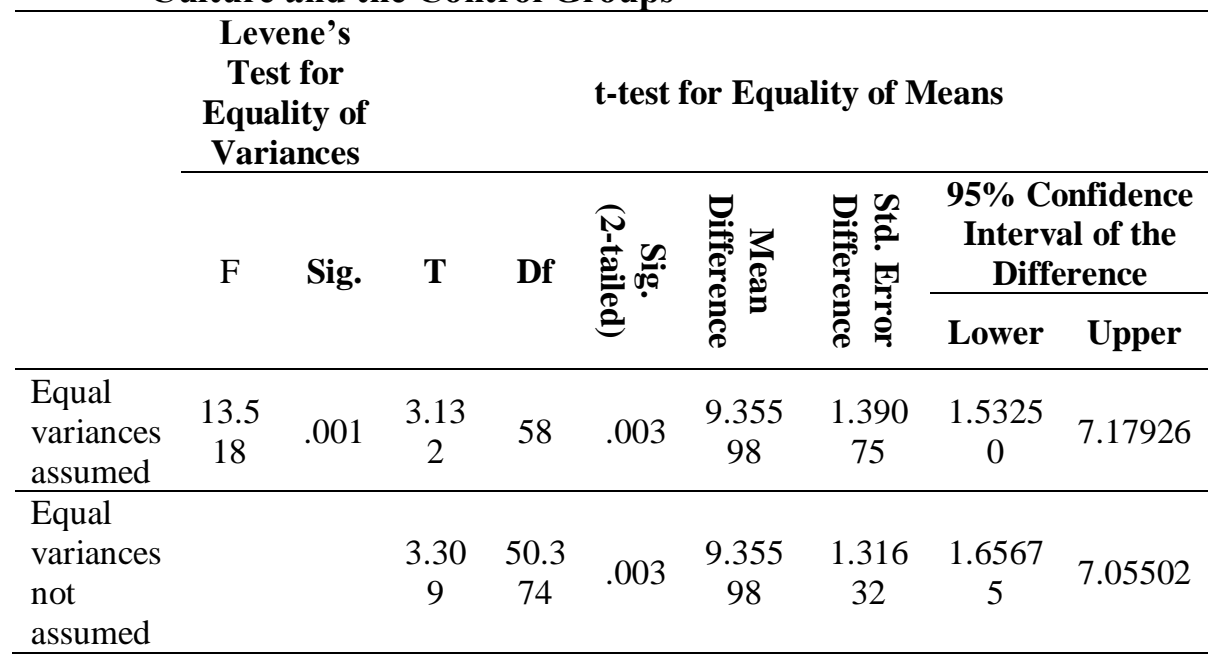

\section{Discussion}

The results of the present study showed that cultural concepts enhance EFL learners' reading comprehension. This finding is in accordance with a number of studies which found that knowing foreign language cultural concepts pave the way of comprehension of reading texts (Jalilifar \& Assi, 2008). The above finding was also supported by Narimani (2017), who stated that learners who are familiar with cultural concepts can understand reading texts better than those who are not. In the same vein, Harmer (2001) and Sadeghi (2014) expressed that a reader should be equipped with some clues in order to understand the intended meaning and concepts of writers. Teachers need to discuss about the new cultural concepts to pave the way of understanding reading for their learners. Thus, learners should be familiar with the language culture that is very important in learning that language and teachers should also use appropriate techniques that can lead to the learners' 
cultural understanding (Dehghan \& Sadighi, 2011; Ghorbandordinejad \& Bayat, 2014; Huang, 2009; Marzban \& Alinejad, 2014).

Although no significant differences were found concerning the reading comprehension ability in the two groups before the treatment, the experimental group outperformed the control group. This finding is in line with those obtained from other studies, e.g. Ghorbandordinejad and Bayat (2014), Liu (2015), and Narimani (2017). These researchers concluded that cultural contents help learners connect what they already know about their home culture to what they are reading and trying to learn in English, and predict what the writer attempts to convey. The researchers also found that cultural contents decrease the cognitive load imposed by the complex reading processes and compensate for the lack of vocabulary that impacts learners' reading comprehension skill.

The findings of this study revealed how reading barriers can be monitored and controlled utilizing cultural texts and reading subjects. This shows that cultural knowledge that learners bring with themselves to the process of reading a passage can really assist them in overcoming their barriers towards reading comprehension and culture. This has been supported by Liu (2015) who examined the effect of cultural background knowledge on EFL learners' reading comprehension. The results of this study showed that cultural background knowledge had a great effect on solving learners' reading comprehension problems and improving their comprehension.

Although majority of the previous studies agree that cultural contents improve learners' reading comprehension skill, research by Stott (2001) proved otherwise. It is said that cultural texts do not guarantee reading recall which leads to reading comprehension. The results of the current study are not supported by the studies of Hudson (1982) and Carrell (1984). They believed that there was no important cultural background effect on learners' reading comprehension skill at advanced levels.

The findings of this study suggest some productive implications in terms of improving reading comprehension through cultural content instruction. Firstly, the study can be of great significance regarding teaching reading skill in educational settings such as institutes. Teachers' awareness of cultural content may help them teach reading more effectively. It can also enhance learners' eagerness, allowing them to have more interaction with their peers as well as the teacher and help them improve their reading skill. Teachers are also the beneficiaries of the findings. As teachers are seeking new and productive 
ways to foster communication in teaching language skills or sub-skills, cultural content instruction can assist them in achieving their goals by involving learners in the more tangible context of learning, which makes the class more enjoyable for them. Finally, since institutes play a significant role in language learning process and the role of learning reading seems to be highlighted in this process, they can benefit from teaching cultural content. In fact, by arming the institutes with cultural content, both teachers and learners can benefit from them to improve their knowledge of reading and other language skills in a rather different learning setting, resulting in learners' possible satisfaction, which is the final purpose any institute serves.

\section{CONCLUSIONS}

This study examined the impact of teaching cultural content on improving Iranian EFL learners' reading comprehension. It was found that teaching cultural content by developing students' cultural background knowledge had significant effects on the learners' reading comprehension. Learners who were made familiar with cultural norms and values, did significantly better on their post-tests. Based on the findings of this study, it is suggested that culture is a basic element for learners to learn and understand their surroundings. Therefore, language instructors should use different cultural values and norms in language teaching programs and pay more attention to their integration and impact. Instructors should consider cultural differences that improve text comprehension. The role of teaching cultural content on Iranian EFL learners' reading comprehension should be recognized as an appropriate methodology, which appears to be beneficial for both learners and teachers in terms of increasing cultural awareness and enhancing reading skills.

\section{REFERENCES}

Al-Issa, A. (2006). Schema theory and L2 reading comprehension: Implications for teaching. Journal of College Teaching \& Learning, 3(7), 41-47.

Allen, D. (1985). Oxford Placement Test. Oxford University Press.

Brantmeier, C. (2004). Building a comprehensive theory of adult foreign language reading: A variety of variables and research methods. In C. Brantmeier (Ed.), Adult foreign language reading: Theory, research, and 
implications. The Southern Journal of Linguistics (pp. 1-6). The University of North Carolina at Charlotte Press.

Brown, H. D. (2001). Teaching by principles: An interactive approach to language pedagogy. Addison Wesley Longgman.

Brown, H. D. (2007). Principles of language learning and teaching ( $5^{\text {th }}$ ed.). Pearson Longman.

Carrell, P. L. (1984). Schema theory and ESL reading: Classroom implications and applications. The Modern Language Journal, 68(4), 332-342.

Carrell, P. L. (1988). Some causes of text-boundedness and schema interference in ESL reading. In P. L. Carrell, J. Devine, \& D. E. Eskey (Eds.), Interactive approaches to second language reading (pp. 101-113). Cambridge University Press.

Choudhury, R. U. (2014). The role of culture in teaching and learning of English as a foreign language. Express: An International Journal of MultiDisciplinary Research, 1(4), 1-20.

Christiansen, M. S., \& Silva, D. (2016). Teaching culture in EFL classrooms in Mexico: Current practices and pedagogical recommendations. MEXTESOL Journal, 40(2), 1-13.

Dehghan, F., \& Sadighi, F. (2011). On the cultural schema and Iranian EFL learners' reading performance: A case of local and global items. PanPacific Association of Applied Linguistics, 15(2), 97-108.

Emsley, M. R. (2011). The effect of cultural background on comprehension of English tests by second language learners of English. (Masters' thesis, University of Limpopo, Limpopo, South Africa). Retrieved from http://hdl.handle.net/10386/577.

Farhadi, H., Jafarpur, A., \& Birjandi, P. (1994). Testing language skills: From theory to practice. The Organization for Researching and Composing University textbooks in the Humanities ((Persian: سازمان مطالعه و تدوين كتب (علوم انسانى دانشخاهها or SAMT.

Ghaderpour, M. (2013). The role of cultural familiarity toward reading comprehension and motivation among Iranian students. (Masters' thesis, Universiti Teknologi Malaysia, Johor Bahru, Malaysia). Retrieved from http://eprints.utm.my/id/eprint/42230/5/MahsaGhaderpourMFP2013.pdf

Ghorbandordinejad, F., \& Bayat, Z. (2014). The effect of cross-cultural background knowledge instruction on Iranian EFL learners' reading comprehension ability. Theory and Practice in Language Studies, 4(11), 2373-2383. 
Guest, M. (2002). A critical 'checkbook' for culture teaching and learning. ELT Journal, 56(2), 154-161.

Gulbinskienè, D., \& Lasauskienè, R. (2014). Intercultural communicative competence (ICC) of EFL students at university level. Žmogus ir žodis/ Svetimosios kalbos [Man and the Word/ Foreign Languages], 16(3), 150159.

Harmer, J. (2001). The practice of English language teaching (3rd Edition). Longman.

Huang, Q. (2009). Background knowledge and reading teaching. Asian Social Sciences, 5(5), 138-142.

Hudson, T. (1982). The effects of induced schemata on the "short circuit" in L2 reading: Non-decoding factors in L2 reading performance. In P. L. Carrell, J. Devine, \& D. E. Eskey (Eds.). Interactive approaches to second language reading (pp. 183-205). Cambridge University Press.

Ibrahim, M. S. (2013). The effect of cultural background knowledge on learning English language. International Journal of Science Culture and Sport, 1(4), 22-32.

Jalilifar, A. R., \& Assi, R. (2008). The role of cultural nativization in comprehension of short stories in EFL reading contexts. The International Journal of Language Society and Culture, 26, 62-79.

Karimi, F., \& Nafissi, Z. (2017). Effects of different culturally-based materials on EFL learners' reading anxiety, reading self-efficacy, and reading proficiency in project-based classes. Issues in Language Teaching (ILT), 6(1), 83-115.

Ketchum, E. M. (2006). The cultural baggage of second language reading: An approach to understanding. Foreign Language Annals, 39(1), 22-42.

Kilickaya, F. (2004). Authentic materials and cultural content in EFL classrooms. The Internet TESL Journal, X(7). Retrieved from http://iteslj.org/Techniques/Kilickaya-AutenticMaterial.html.

Liu, Y. C. (2015). The perception of cultural familiarity and background knowledge on reading comprehension for intermediate EFL students. International Journal of Language and Literature, 3(1), 71-75.

Marzban, A., \& Alinejad, F. (2014). The effect of cooperative learning on reading comprehension of Iranian EFL learners. Procedia-Social and Behavioral Sciences, 116, 3744-3748. 
Garth-McCullough, R. (2008). Untapped cultural support: The influence of culturally bound prior knowledge on comprehension performance. Reading Horizons: A Journal of Literacy and Language Arts, 49(1), 1-31.

McKay, S. L. (2000). Teaching English as an international language: Implications for cultural materials in the classroom. TESOL Journal, 9(4), 7-11.

Narimani, R. (2017). The effects of cross cultural background knowledge on Iranian EFL learners' reading comprehension at two levels of language proficiency. Journal of Applied Linguistics and Language Research, 4(4), 210-223.

Rashidi, N., \& Heidari Soureshjani, K. (2011). The effect of teaching culturally-based texts on the Persian English as a foreign language (EFL) learners' motivation and reading performance. Journal of Languages and Culture. 2(8), 141-147.

Sadeghi, M. (2014). The impact of cultural orientation on EFL learners' reading comprehension and achievement motivation. Journal of Teaching English Language Studies, 2(4), 36-49.

Schulz, R. A. (2007). The challenge of assessing cultural understanding in the context of foreign language instruction. Foreign Language Annals, 40(1), 9-26.

Serna Dimas, H. M. (2016). Integrating the intercultural communicative competence (ICC) in a foreign language program: Faculty considerations upon leaving the haven of native speakership. English Language Teaching, 9(4), 1-10.

Shanahan, D. (1997). Articulating the relationship between language, literature and culture: Toward a new agenda for foreign language teaching and research. The Modern Language Journal, 81(2), 164-174.

Stott, N. (2001). Helping ESL students become better readers: Schema theory applications and limitations. The Internet TESL Journal, VII(11). Retrieved from http://iteslj.org/Articles/Stott-Schema.html.

Stuart. G., \& Nocon, H. (1996). Second culture acquisition: Ethnography in the foreign language classroom. The Modern Language Journal 80(4), 431449

Tomalin, B. (2008). Culture - the fifth language skill. Retrieved from http://www.teachingenglish.org.uk/article/culture-fifth-language-skill

Tseng, Y. (2002). A lesson in culture. ELT Journal, 56(1), 11-21. 
Razavi \& Gilakjani, The Effect of Teaching Cultural Content on Reading 321

Tsou, W. (2005). The effects of cultural instruction on foreign language learning. RELC, 36(1), 39-57.

Wang, X. Y. (2008). Reflection on the notion of culture teaching. US-China Foreign Languages, 6(1), 49-53. 